\title{
PKM PENDAMPINGAN KELOMPOK TANI "PINTOE RIMBA" DESA NAGA UMBANG, ACEH BESAR MELALUI PENGEMBANGAN ALAT DESTILASI
}

\author{
Sholihati $^{1}$, Ruka Yulia ${ }^{2}$, Kiman Siregar ${ }^{3}$, Lukmanul Hakim ${ }^{2}$, dan Fadlan Hidayat ${ }^{2}$ \\ ${ }^{1}$ Prodi Teknik Industri Pertanian, Fakultas Teknologi Pertanian, Universitas serambi Mekkah, \\ ${ }^{2}$ Prodi Teknologi Pangan, Fakultas Teknologi Pertanian, Universitas Serambi Mekkah, \\ ${ }^{3}$ Prodi Teknik Pertanian, Fakultas Pertanian,Universitas Syiah Kuala; \\ e-mail: sholihati.usm@gmail.com
}

\begin{abstract}
Abstrak
Pembuatan minyak herbal tradisional di Kelompok Tani "Pintoe Rimba" Desa Naga Umbang Kecamatan Lhoknga Aceh Besar masih dilakukan secara tradisional. Tidak hanya bahan dasar seperti minyak tanaman sere wangi yang harus di beli dari luar namun pengemasan pun masih dilakukan secara sederhana. Pendampingan pengoptimalan pembuatan minyak dilakukan untuk meningkatkan keterampilan pembuatan minyak herbal tradisional, peningkatan standar mutu minyak herbal tradisional serta keberlanjutan produksi minyak herbal guna meningkatkan standar ekonomi di kelompok tani. Bahan utama dalam kegiatan ini merupakan bahan alami yaitu minyak sere wangi, minyak gandapura, jahe, kencur, cengkeh serta bahan alami lainnya. Sedangkan alat yang digunakan meliputi alat destilasi untuk menyuling minyak dan alat untuk melakukan kegiatan pengemasan minyak. Tahapan pelaksanaan kegiatan ini meliputi: 1) Tahapan Sosialisasi Kegiatan, 2) Tahapan penyuluhan mengenai peningkatan ekonomi keluarga dan wirausaha. 3) Tahapan pelatihan mendesain kemasan dan pelabellan, 4) pengembangan alat destilasi minyak, 5) Tahapan pengoptimalan pembuatan minyak herbal melalui pelatihan pembuatan minyak dengan alat yang lebih modern, 6) Tahapan pendampingan dalam pemasaran minyak. Indikator keberhasilan atau target/luaran yang kami harapkan berhasil dalam kegiatan ini adalah: a) Mitra pengabdian memiliki pengetahuan mengenai peningkatan ekonomi keluarga dan wirausaha, b) Mitra pengabdian mampu mengemas dan memberi label pada produk minyak herbal tradisional yang diproduksi dengan menggunakan sealer yang lebih modern, c) Mitra pengabdian memiliki beberapa alat yang lebih modern yang meningkatkan kegiatan produksi minyak herbal tradisional, d) Mitra pengabdian memiliki standar mutu minyak yang lebih baik dari sebelumnya, e) Mitra mampu meningkatkan pemasaran minyak sehingga mampu meningkatkan ekonomi keluarga.
\end{abstract}

Kata Kunci: Minyak Herbal, Pintoe Rimba, Optimalisasi, Destilasi, Pengemasan, Peningkatan Ekonomi

\section{A. Pendahuluan}

Penggunaan bahan alami sebagai obat tradisional memiliki prospek yang sangat cerah dimasa yang akan datang. Supardi, dkk. (2010) mengungkapkan pengunaan obat 
tradisional mengalami peningkatan selama 7 tahun terakhir dari jumlah 15,2\% menjadi 38,30\%. Didukung dengan kekayaan Indonesia yang kaya akan sumber daya alam, maka sangat mendukung pemanfaatannya sebagai sumber pengobatan alami dan tradisional. Beberapa kekayaan sumber daya alam tersebut seperti tanaman sere wangi, cengkeh, jahe, kencur dan lain sebagainya. Faktor lain yang turut berperan dalam penggunaan obat tradisional diantaranya 1) keanekaragaman hayati pada kekayaan alam Indonesia, 2) kebiasaan nenek moyang dalam pengobatan tradisional, 3) adanya peningkatan pasar produk herbal melalui Isu global "back to nature", 4) menurunnya daya beli dan tingkat perekonomian masyarakat, sehingga masyarakat banyak beralih ke pengobatan tradisional dan herbal.

Penggunaan obat tradisional salah satunya minyak pijat dan urut sudah lama dilakukan secara turun temurun. Urut tidak hanya dilakukan pada otot namun juga jalur saraf. Hal ini bertujuan untuk mendorong sirkulasi darah yang lebih baik yang dilakukan dengan gerakan yang dilakukan dengan tekanan yang lebih kuat dan memerlukan keterampilan tambahan (Anonymous, 2014). Di Indonesia, selama berabad-abad tahun yang lalu, istilah pijat dan urut telah lama dikenal. Hal ini dibuktikan dengan relief batu Borobudur yang ada di Jawa Tengah, dimana terdapat ukiran raja dan ratu yang sedang di pijat oleh dayang-dayang. Pijat merupakan cara tradisional yang digunakan untuk relaksasi dan meringankan rasa tubuh dengan melemaskan otot-otot yang kaku dengan gerakan meremasremas. Sedangkan urut digunakan untuk mengobati cidera yang lebih serius dan patah tulang.

Pengembangan minyak tradisional telah banyak dilakukan, salah satunya yang dilakukan oleh Setyawan (2012) pada kencur yaitu membuat minyak atsiri dari kencur dimana hasilnya perbandingan serbuk kencur, etanol dan lama operasi berpengaruh pada yield dan kualitas oleoresin. Kondisi optimal ekstraksi terdapat pada perbandingan serbuk kencur: etanol adalah 1:4 dan waktu ekstraksi 3,62 jam. Begitu pula pada jahe (Zingiber oficinale), salah satu penelitian yang dilakukan oleh Rusnoto (2015) bahwa terjadi perubahan setelah pengompresan untuk meringkankan skala nyeri asam urat Di Desa Kedungwungu Kecamatan Tegowanu Kabupaten Grobokan. Adapun cengkeh (Syzygium aromaticum) menurut Towaha (2012) mengandung minyak eugenol yang dapat digunakan oleh berbagai industri di Indonesia. Seperti indusrtri farmasi, kosmetika, makanan, minuman, rokok, pestisida nabati, perikanan, pertambangan, kemasan aktif. Arpi (2013) turut mengembangkan minyak pilek $u$ atau minyak kelapa sawit sebagai bahan baku pembuatan minyak kemenyan 
dengan lama pemanasan 2 jam menghasilkan minyak kemenyan yang hampir sama mutu kimia dan organoleptiknya ,kecuali kandungan iod yang tinggi pada minyak kemenyan dari kelapa sawit.

Salah satu kelompok tani Aceh yang berusaha mengembangkan pembuatan minyak herbal tradisional untuk minyak urut dengan berbahan alami adalah Kelompok Tani "Pintoe Rimba" Desa Naga Umbang Kecamatan Lhoknga Aceh Besar. Namun permasalahan yang ada adalah Kelompok Tani ini masih menggunakan cara tradisional dan masih sangat sederhana dalam proses pembuatan minyak herbal tersebut sehingga belum memberikan hasil ekonomi secara nyata. Padahal jika produk ini dapat dikembangkan secara maksimal maka besar kemungkinan dapat menjadi salah satu produk komersial dimasa yang akan datang. Sementara ini kelompok Tani "Pintoe Rimba" membuat minyak herbal tradisonal dengan menumbuk bahan dasar cengkeh, kencur dan jahe lalu dicampurkan dengan minyak tanah untuk penyakit kembung perut dan dicampur dengan minyak makan sebagai obat urut/pijat, selain itu bahan dasar pembuat minyaknya seperti minyak sere wangi masih dibeli dan tidak diproduksi sendiri karena minimnya peralatan. Dengan minimimnya peralatan pembuatan minyak herbal, sederhananya sistem kemasan serta rendahnya pengetahuan serta keterampilan dalam membuat minyak herbal tradisional mendorong tim pengabdian untuk melakukan pendampingan di Kelompok Petani "Pintoe Rimba" Desa Naga Umbang Kecamatan Lhoknga Aceh Besar melalui pengoptimalan pembuatan minyak herbal.

Solusi permasalahan yang selanjutnya akan kami laksanakan pada PKM kali ini adalah: 1) Mengadakan upaya motivasi dan transfer ilmu mengenai peluang usaha dan wirausaha melalui sosialisasi ke kelompok tani, (2) Pegembangan alat destilasi minyak, 3) pengoptimalan pembuatan produksi minyak herbal tradisional; dengan cara mengadakan peningkatan keterampilan melalui pelatihan pembuatan minyak herbal dengan alat penyulingan dengan alat destilasi sederhana, 4) Memperbaiki sistim kemasan melalui kegiatan pelatihan pengemasan dan Pelabellan, hal ini didukung oleh Syarief, dkk. (1989) bahwa kegiatan pengemasan merupakan sistem yang terkoordinasi untuk menyiapkan barang menjadi siap untuk ditransportasikan, didistribusikan, di simpan, di jual, dan di pakai, demikian juga dalam kegiatan labelling berisi keterangan produk, tidak boleh mudah lepas, luntur atau lekang karena air, gosokan atau pengaruh sinar matahari. Sehingga dua kegiatan ini sangat berperan dalam mendukung pemasaran 5) Melakukan Pendampingan dalam pemasaran. 


\section{B. Masalah}

Permasalahan yang ada dalam pengabdian kepada masyarakat yang dilaksanakan pada Kelompok Tani "Pintoe Rimba” Desa Naga Umbang Kecamatan Lhoknga Aceh Besar adalah kelompok tani ini masih menggunakan cara tradisional dan masih sangat sederhana dalam proses pembuatan minyak herbal, sehingga belum memberikan hasil ekonomi secara nyata.

\section{Metode Pelaksanaan}

Metode pelaksanaan dari PKM ini diawali dengan penentuan lokasi Program Kemitraan Masyarakat (PKM) yaitu Desa Naga Umbang Kecamatan Lhoknga, Aceh Besar. Sasaran PKM ini merupakan masyarakat yang tergabung dalam Kelompok Tani "Pintoe Rimba" Desa Naga Umbang Kecamatan Lhoknga Aceh Besar. Dalam kegiatan ini melibatkan 2 (dua) mahasiswa dari Universitas Syiah Kuala Banda Aceh.

Bahan utama dalam kegiatan ini adalah terdiri dari bahan alami yaitu tanaman sere wangi, jahe, kencur dan cengkeh dan lain-lain. Sedangkan alat yang digunakan dalam kegiatan ini meliputi alat destilasi, alat penumbuk, pisau, baskom, talenan.. Untuk pengemasan produk menggunakan botol., label dan penutup botol.

Metode Pelaksanaannya dilaksanakan melalui penyuluhan, diskusi dan praktik/demonstrasi secara langsung di lapangan. Dalam pelaksanaamya ada yang dilakukan secara general dan ada juga yang di bagi menjadi beberapa kelompok kecil sebanyak 5 orang per kelompok. Kegiatan penyuluhan diberikan secara tutorial dengan memberikan modul yang berisikan tentang pengenalan alat dan cara penggunaan alat produksi minyak herbal tradisional serta teknik pengemasan minyak herbal.

\section{Pembahasan}

Kegiatan pengabdian kepada masyarakat ini telah dilaksanakan berupa:

1. Mengadakan Upaya Motivasi dan Transfer Ilmu Mengenai Peluang Usaha Dan Wirausaha Melalui Sosialisasi dan Penyuluhan Ke Kelompok Tani,

Dalam kegiatan penyuluhan mitra diberikan bekal tentang pentingnya berusaha agar dapat meningkatkan ekonomi keluarga mengenai bagaimana memanfaatkan peluang usaha yang ada disekitar lingkungan tempat tinggal mitra. Dengan adanya transfer ilmu tersebut diharapkan masyarakat Kelompok Tani "Pintoe Rimba" Desa Naga Umbang Kecamatan 
Lhoknga Aceh Besar memiliki semangat dan kepercayaan diri dalam berwirausaha serta merubah pola pikir masyarakat tentang peningkatan ekonomi keluarga. Kegiatan Dalam tahapan ini sebelumnya dilakukan sosialisasi dengan menghubungi Ketua Kelompok Tani untuk mendiskusikan sekaligus meminta ijin serta berkoordinasi agar Program Kemitraan Masyarakat (PKM) ini dapat berlangsung dengan lancar.
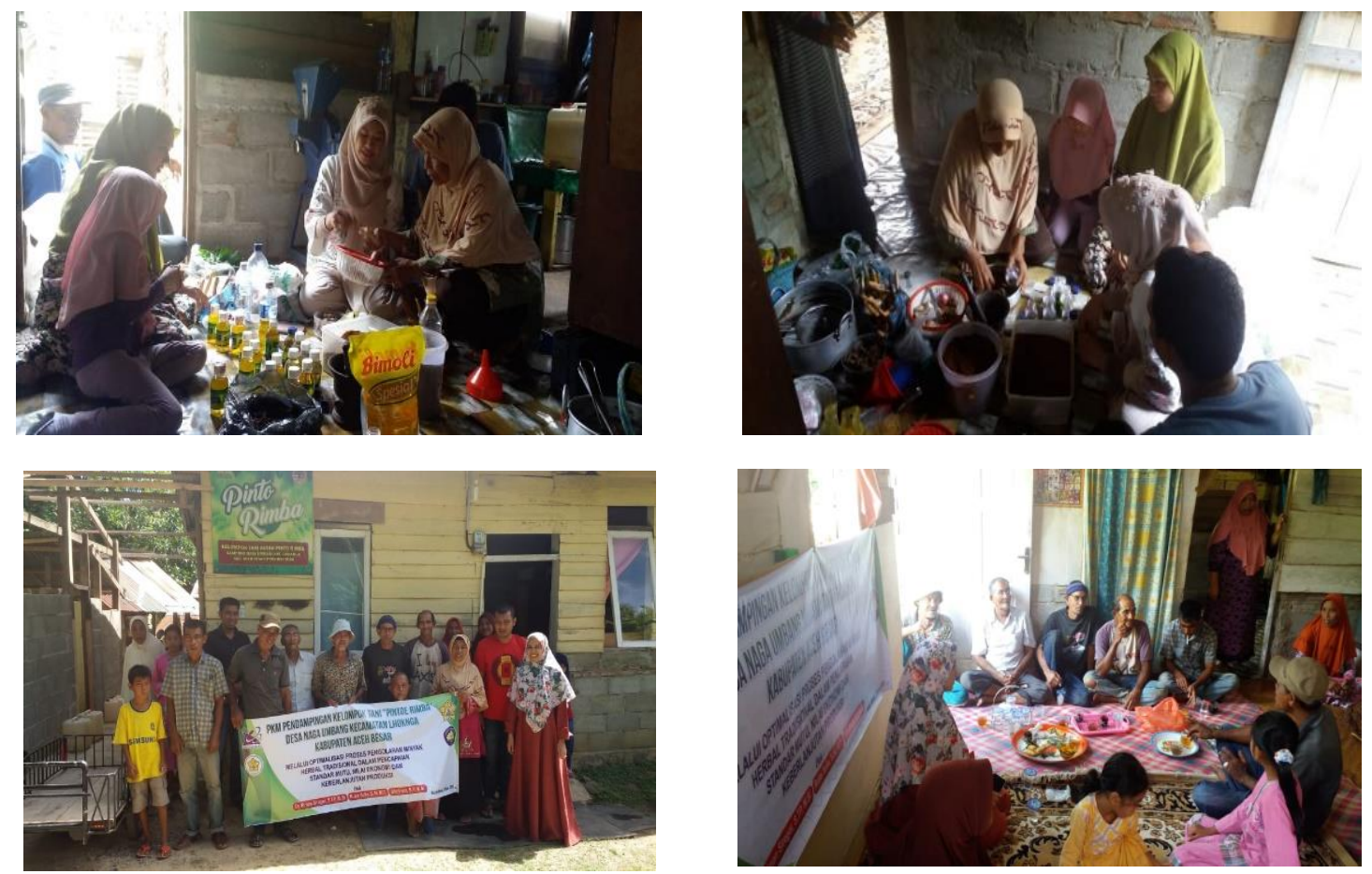

Gambar 1. Kegiatan Sosialisasi dan Penyuluhan PKM ke Kelompok Minyak Urut "Pintoe Rimba"

2. Pengembangan dan Pelatihan Pembuatan Minyak Herbal Berbahan Alami Melalui Alat Destilasi Berkapasitas $5 \mathrm{Kg}$

Tahapan ini merupakan rangkaian dalam kegiatan pengabdian, karena khususnya kelompok Tani "Pintoe Rimba" sementara ini membuat minyak herbal tradisonal dengan menumbuk bahan dasar cengkeh, kencur dan jahe lalu dicampurkan dengan minyak tanah untuk penyakit kembung perut dan di campur dengan minyak makan sebagai obat urut/ pijat, kemudian di masak dan di saring. Dalam pelaksanaannya pembuatan minyak ini dilakukan secara tradisional seperti pembelian minyak sere yang tidak di produksi secara mandiri namun di beli dengan harga yang cukup mahal. Dengan demikian, diperlukan pengoptimalan pembuatan minyak herbal melalui suatu alat modern untuk membuat bahan 
dasar minyak sere wangi sehingga proses pembuatan minyak herbal tidak sepenuhnya dilakukan secara manual. Tim pengabdian mengembangkan sebuah alat penyulingan minyak modern di mana diharapkan dapat membantu kelompok tani dari hilir ke hulu, yang mendorong petani untuk menanam tanaman sere wangi sebagai dasar pembuatan minyak. Alat destilasi ini menggunakan bahan stainless stell berkapasitas 5 kilogram.

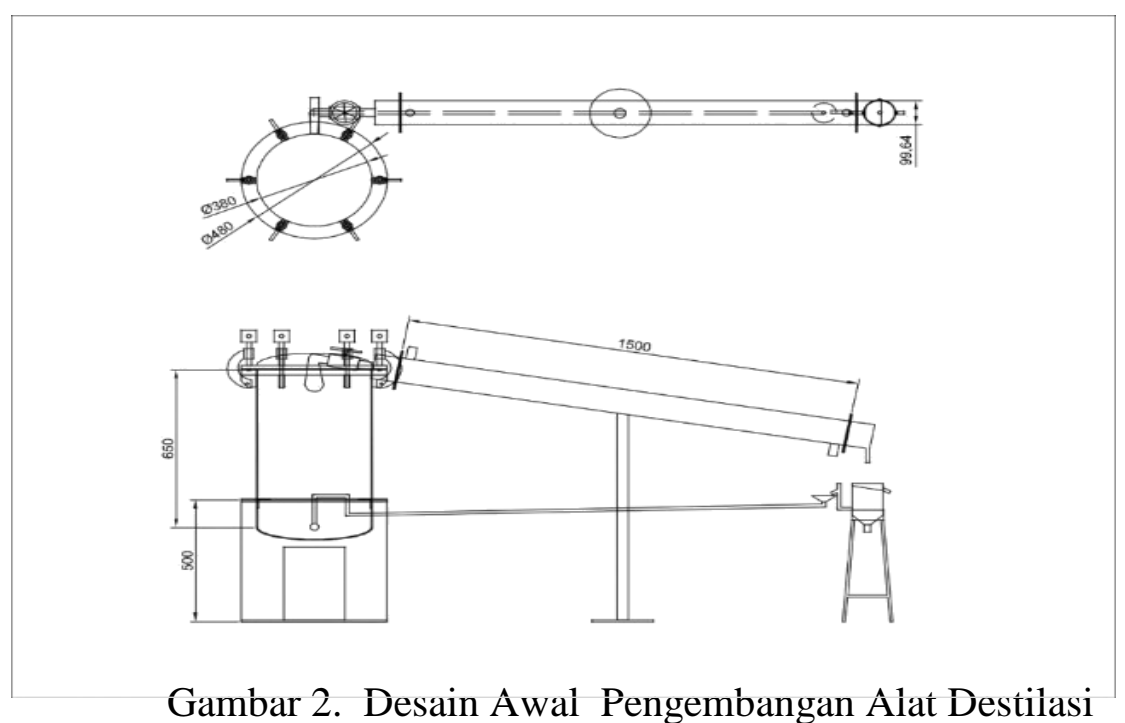

Alat destilasi ini berkapasitas $5 \mathrm{~kg} /$ proses dengan diameter ketel kurang lebih $380 \mathrm{~mm}$ dan tinggi $650 \mathrm{~mm}$. Pendingin dikembangkan dengan model multi turbin dengan diameter 4 inchi, panjang 1,5 meter dengan bahan stainless steel. Pemanas dilakukan dengan LPG. Pengembangan alat destilasi ini dilengkapi dengan tabung pemisah minyak, pressure gauge, thermometer, safety valve, tungku pembakaran dan kompor gas.

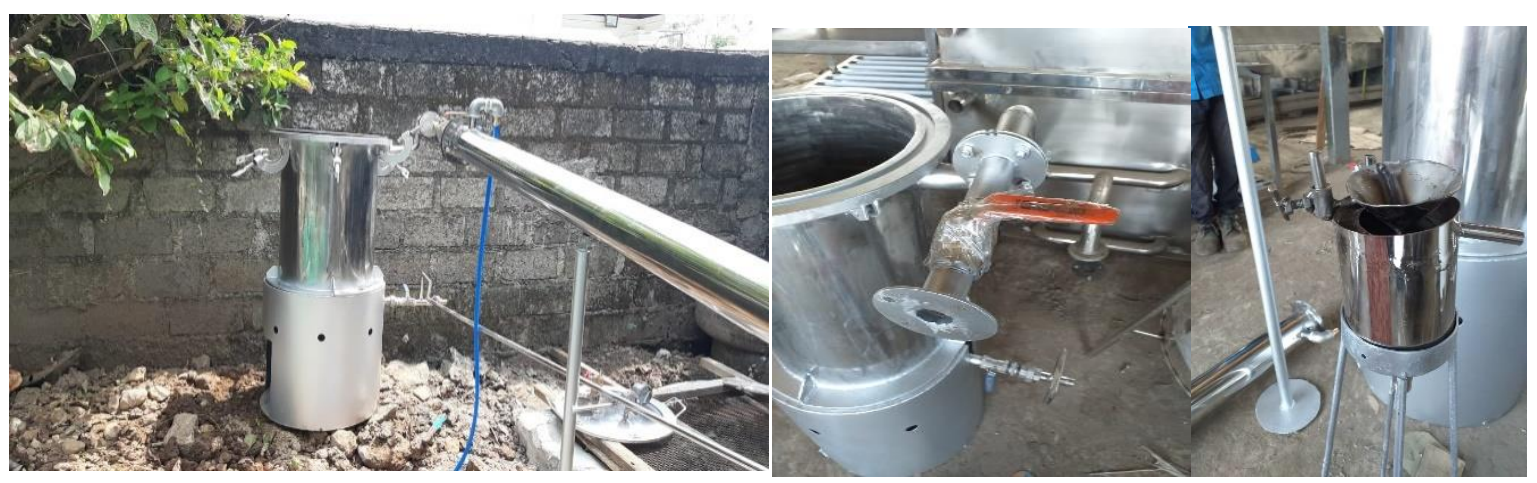

Gambar 3. Alat Destilasi yang Sudah Jadi Dengan Kapasitas 5 kg

Dalam kegiatan ini setelah alat destilasi sudah berhasil dikembangkan maka dilakukan sosialisasi pengguaan alat destilasi ke kelompok tani dengan mempersiapkan bahan 
tanaman sere wangi dengan kapasitas $5 \mathrm{~kg}$ yang selanjutnya dimasukkan ke dalam alat destilasi.

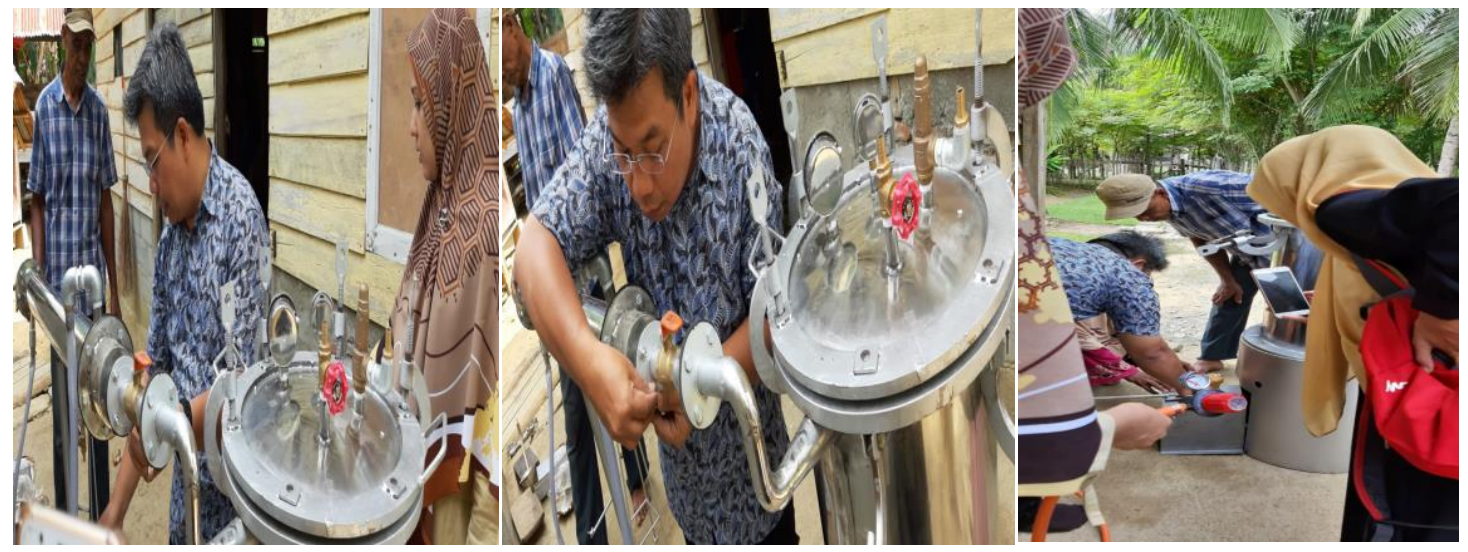

Gambar 4. Pelatihan Penggunaan Alat Destilasi

Adapun alir proses pembuatan minyak "Pintoe Rimba" Naga Umbang
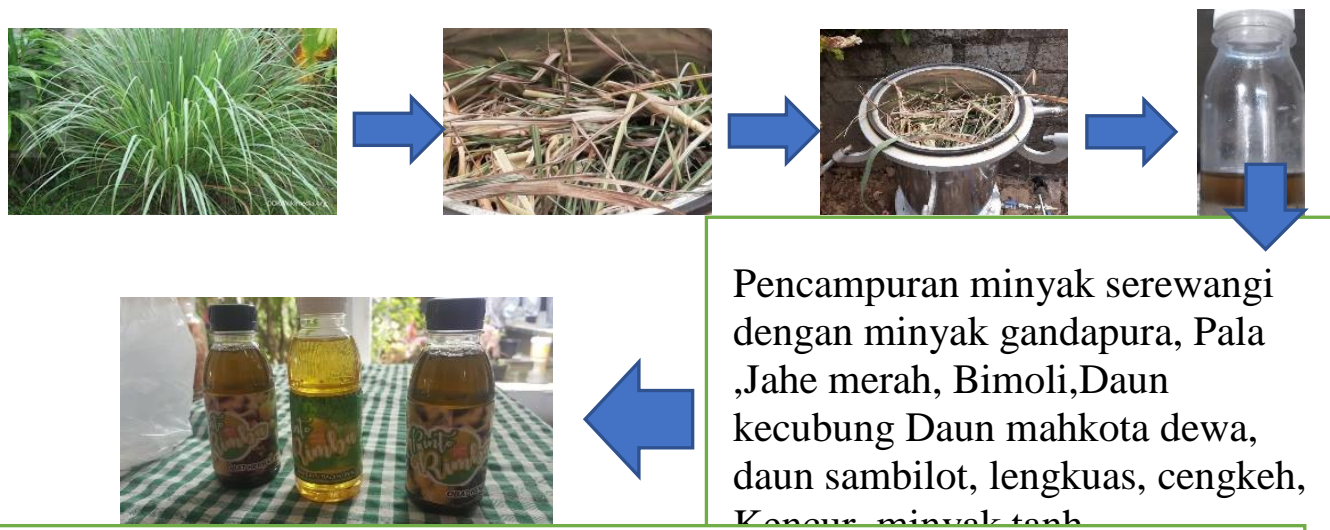

Pencampuran minyak serewangi dengan minyak gandapura, Pala ,Jahe merah, Bimoli,Daun kecubung Daun mahkota dewa, daun sambilot, lengkuas, cengkeh,

Gambar 5. Alir Pembuatan Minyak "Pintoe Rimba: Naga Umbang

3. Tahapan Pelatihan Mendesain Kemasan dan Pelabellan

Pelatihan pengemasan ini di buat untuk mengemas produk minyak herbal yang telah di buat agar lebih menarik dan mampu meningkatkan nilai jual produk minyak herbal yang dihasilkan. Dalam tahap ini akan diperkenalkan alat pengeseal tutup botol yang lebih efektif untuk mengemas minyak herbal, mengemas minyak sehingga secara eye catcing menarik pembeli. Dalam tahap ini pengemasan sebenarnya sudah dilakukan secara baik dan menggunakan botol kemasan khusus namun dalam pelaksanaannya penggunaan dilakukan dengan pelilinan dilakukan dengan menggunakan hair dyer untuk melakukan pengepresan pada labellingnya. 

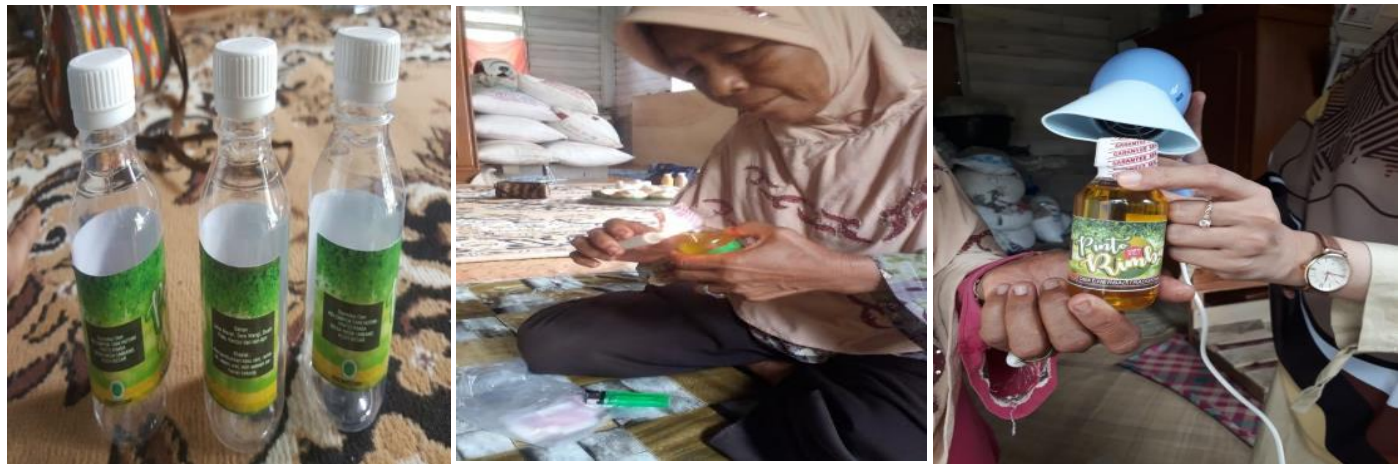

Gambar 6. Kemasan Botol Minyak Urut "Pintoe Rimba" (Kiri) dan Pengemasan Yang Masih Dilakukan Secara Tradisional Dengan Lilin (Tengah) dan Pengemasan Dengan Hairdryer (Kanan).

\section{Tahapan Pendampingan Selama Kegiatan dan Pemasaran}

Kegiatan pendampingan dilakukan selama proses pelaksanaan kegiatan pengabdian kepada masyarakat. Selain itu pendampingan yang dilakukan dengan kelompok tani ini adalah di bidang pemasaran, yang dilakukan melalui beberapa kegiatan baik offline maupun online. Selain secara langsung dari rumah ker rumah, pendampingan yang dilakukan adalah melalui "Minyak Naga Umbang Goes To Campus". Dengan kegiatan ini team pengabdian mendampingi kelompok tani ini dalam memperkenalkan minyak "Pintoe Rimba" ke kalangan civitas akademika. Kegiatan yang dilakukan di sekitar Universitas Serambi Mekkah (USM) Banda Aceh. Dalam kegiatan ini dikenalkan juga tahapan kegiatan dan proses pembuatan minyak melalui flyer dan poster yang telah di buat. Selain itu kegiatan pemasaran secara langsung dilakukan dengan mendorong kelompok tani untuk mengikuti setiap kegiatan yang dilakukan oleh pemerintah daerah seperti yang dilakukan Dinas Pertanian dan Perkebunan Aceh yang dilakukan setiap Rabu di lingkungan dinas. Kelompok tani ini kami dorong untuk mengikuti kegiatan tersebut sehingga minyak Naga Umbang lebih di kenal oleh masyarakat luas.

Pendampingan pemasaran juga dilakukan melalui media online yaitu media sosial seperti tokopedia, facebook, instagram maupun whatssapps. Beberapa informasi terkait pemasaran minyak "Pintoe Rimba" Naga Umbang dapat di lihat di https//www.tokopedia.com, https://www.facebook.com, dan https://www.facebook.com dan serambi news. Anwar, dkk. (2019) menjelaskan bahwa pemasaran minyak dapat dilakukan secara online maupun offline. Sehingga banyak cara yang dilakukan untuk meningkatkan nilai jual minyak urut tersebut. 

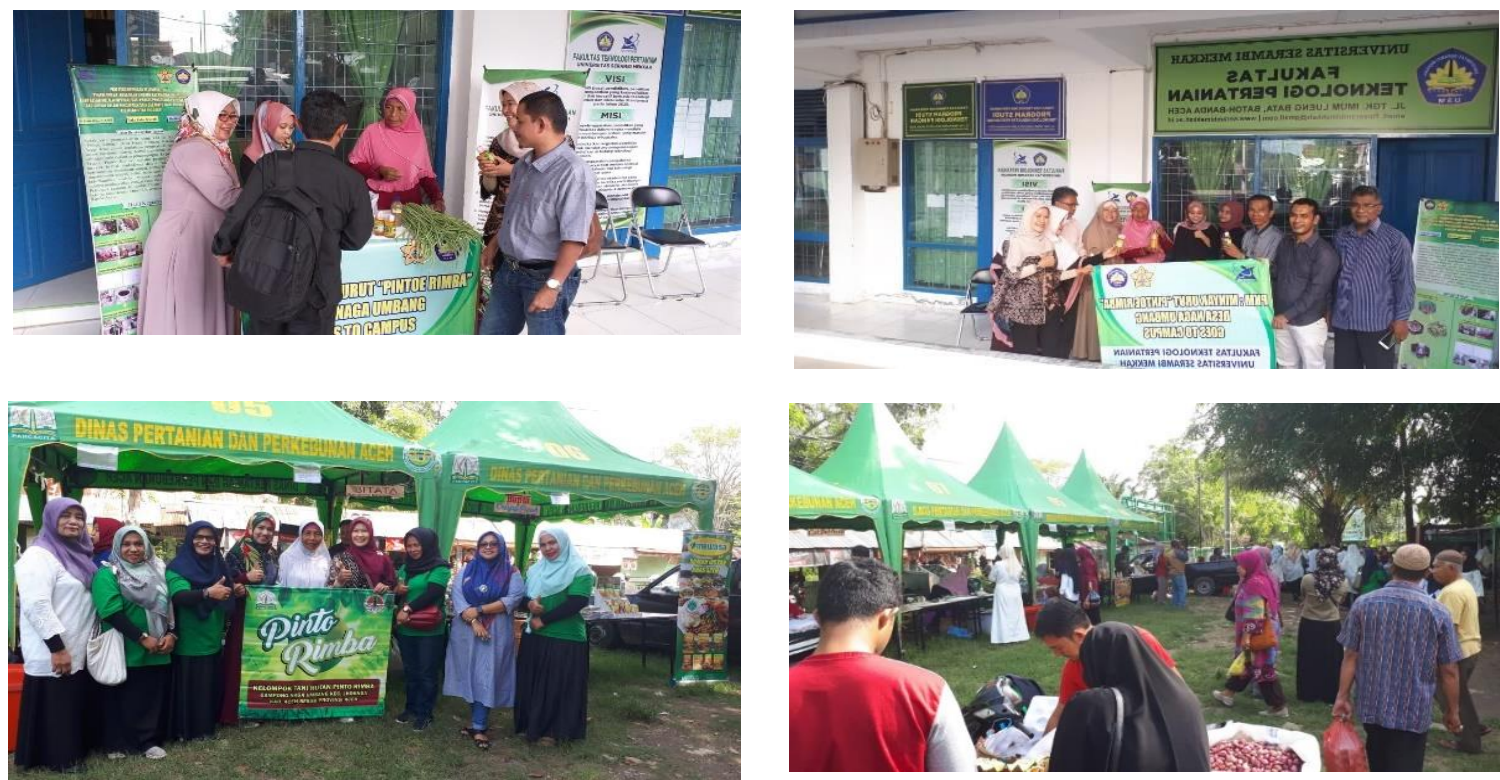

Gambar 7. Pendampingan Pamasaran Melalui "Minyak Naga Umbang Goes To Kampus" dan Pendampingan di Pasar Tani yang Dilaksanakan Setiap Rabu Oleh Dinas Perkebunan dan Pertanian Aceh

\section{E. Kesimpulan}

Kegiatan pengabdian kepada masyarakat ini dilakukan melalui pengembangan alat penyulingan minyak yang lebih efisien dalam mengoptimalisasikan produksi minyak herbal kelompok tani Pintoe Rimba. Kegiatan PKM menghasilkan berbagai capaian bagi mitra pengabdian diantaranya adalah mitra sudah mulai termotivasi untuk meningkatkan perekonomian keluarga dengan berwirausaha memanfaatkan potensi alam sekitar, mitra telah cukup cakap dan terampil mengolah bahan alami menjadi minyak herbal tradisional menggunakan alat penyulingan, produk minyak herbal milik mitra memiliki standar mutu minyak yang lebih baik dari sebelumnya, mitra sudah mampu mengemas dan memberikan label pada produk minyak herbal tradisional dengan menggunakan alat pengeseal yang lebih cepat. Keberadaan produk minyak urut herbal milik mitra telah di kenal oleh masyarakat di Kota Banda Aceh dan Aceh Besar melalui berbagai cara pemasaran seperti pasar tani, Minyak Naga Umbang Goes To Campus maupun media online. 


\section{F. Ucapan Terima Kasih}

Terima kasih kepada Direktorat Jenderal Riset dan Pengembangan, Kementerian Riset Teknologi dan Pendidikan Tinggi (DPRM Kemenristek Dikti) yang telah mendanai pengabdian kepada masyarakat ini. Juga kepada Tim pengabdian kolaborasi dari dua universitas yaitu Universitas Serambi Mekkah dan Universitas Syiah Kuala. Tidak lupa ucapan terima kasih juga kami sampaikan kepada Kelompok Tani "Pintoe Rimba" yang menjadi mitra dalam kegiatan pengabdian ini.

\section{DAFTAR PUSTAKA}

Anonymous. (2014). Apa Itu Pijat dan Apa Itu Urut. Di Upload tanggal 16 Agustus.http://dietwanita.blogspot.com/2014/08/apa-itu-pijat-dan-apa-itu-urut.html.

Anwar, dkk. (2019). Pemberdayaan Masyarakat Dalam Produksi Minyak Sereh Wangi di Kelurahan Pondok Petir Kecamatan Bojong Sari Depok Jawa Barat. Jurnal Ilmiah Widya Eksakta. Volume 1 No 2 Mei 2019.

Arpi. (2013). Pembuatan Minyak Kemenyan (Minyak Obat Tradisional Khas Aceh) dengan Variasi Bahan Baku Minyak dan Konsentrasi Bahan Pewangi. Jurnal Teknologi dan Pertanian Indonesia. Vol 5 No 1. hal 17-22.

Rusnoto. (2015) .Pemberian Kompres hangat Menakai Jahe Untuk Meringankan Skala Nyeri Pada Pasien Asam Urat di Desa Kedungwungu Kecamatan Tegowanu Kabupaten Grobokan.. JIKK Vol 6 No 1, hal 29-39.

Setyawan, dkk. (2012). Optimalisasi Yield Etil P Metoksisinamat Pada Ekstraksi Oleorisin Kencur (Kaempferia galanga) Menggunakan Pelarut Etanol. Jurnal Bahan Alam Terbarukan. Vol 1 No 2 Desember. hal 31-38.

Supardi. (2010). Penggunaan Obat Tradisional Dalam Upaya Pengobatan Sendiri di Indonesia (Analisis Data Susenas Tahun 2007). Buletin Penelitian Kesehatan (Bulletin of Health Research) .Vol 38. No.2 . hal 80-89.

Towaha. (2012). Manfaat Eugenol Cengkeh Dalam Berbagai Industri di Indonesia. Jurnal Perspekif Vol. 11 No.2 Dessember. hal 79-90. 